\title{
Cross Listing, Bonding, and Earning Qualities
}

\author{
Hong YUE*
}

School of Economics and Management,

Beijing Information Science and Technology University, China

yuehong2016@163.com

${ }^{*}$ Corresponding author

Keywords: cross listing, bonding mechanism, earning qualities

\begin{abstract}
Using the accounting conservatism, value relevance and earning management as the measure for cross listing bonding effect, this paper tests the existence of bonding effect for cross listing firms. The result shows that bonding effect exists in firms which list in Hong Kong, and the effect significantly improves firms' earning qualities.
\end{abstract}

\section{Introduction}

Cross listing as an important way for enterprises internationalization, many Chinese state-owned enterprises and high-tech private enterprises in recent years have listed abroad, and Hong Kong as a developed capital markets areas which can equivalent as overseas capital market, has been the first choice for Chinese enterprises when choosing the location of overseas. The motivations of enterprises cross listing mainly include reducing the negative effects of market segmentation, generating financing value; enhancing the price discovery function so as to increase companies' stock market liquidity; improving the publicity of the company, which can get a large number of analyst research and media reports, and having the advertising effect(Doidge, Karolyi and Stulz, 2004) ${ }^{[1]}$. However, the above theories have not obtained consistent evidences. Until Bonding Theory was proposed by Coffee $(1999,2002)^{[2] ~[3]}$ and Stulz $(1999)^{[4]}$, the behavior of cross listing for enterprises gets a better explanation. Bonding theory believes that, investors who are in underdeveloped capital markets worry about the controllers of the company to grab private interests, and often protect themselves through the discount, which resulting in companies bearing a higher cost of capital and reducing the value of the company; if companies cross list in more developed capital markets, bond their behaviors and the new market and institutional environment together, accept more stringent legal regulatory and market constraints, they can effectively solve the commitment problem, obtain the trust of investors, reduce financing costs and enhance the value of the companies. Although there is not much controversy about the existence of bonding mechanism and the functional mechanism theoretically, research empirical evidences are not uniform. Foerster and Karolyi (1999) ${ }^{[5]}$, Lang et $(2003)^{[6]}$ and Bauer (2004) ${ }^{[7]}$ and many other literatures provide consistent evidences with bonding theory from different market reaction perspectives about cross listings, such as the cost of capital, the value of the company, information environment, corporate governance and so on. However, Licht (2003) and Siegel (2005) provide evidence that overseas listing may not be able to play a bonding role, they believe that the local judicial and regulatory are properly failed with the foreign companies ${ }^{[8,9]}$. Furthermore, there are few scholars to verify the bonding mechanism combined with China's situation. This paper uses earning qualities as the measure of the bonding effect, chooses companies which issue $\mathrm{A}$ shares and $\mathrm{H}$ shares at the same time as the researching object, and further study the bonding effect of Chinese mainland companies which listed overseas.

\section{Institutional Background and Research Hypotheses}

\subsection{Institutional Background for Enterprises Listed in Hong Kong}

The overseas developed capital market provides new opportunities for our developing country. 
Some countries which have similar investor protection level as the United States market are attracting more and more companies to list, and Hong Kong as an area which has matched the developed degree with overseas capital market also attracted a group of the mainland's enterprises because of its huge potential. And as Hong Kong has carried out the cancellation of the $\mathrm{H}$ shares double audit policy to reduce the cost, to some extent, it promotes the mainland enterprises to Hong Kong listing. As a region owning relative perfect capital market development, China's enterprises would like to choose Hong Kong as the first listed abroad.

In this study, the reasons why the enterprises listed in Hong Kong are equivalent to the overseas listing which mainly have three following aspects. First, the CSRC's overseas listing guidelines include listings in Hong Kong, even after 1997.Specifically, the CSRC's overseas listing guidelines state, "3. Procedures for application and approval (1) The company concerned shall submit the documents to the CSRC before submitting to the overseas securities regulatory authority or exchange (for example, submitting to the Stock Exchange of Hong Kong Limited).'Second, after Hong Kong's reunification with China in 1997, the Chinese government established Hong Kong as a special administrative region (SAR) and guaranteed the region a high degree of autonomy for at least 50 years. Third, the characterization of a Hong Kong listing as an overseas listing is consistent with prior literature that notes the legal environment in Hong Kong resembles those of other foreign markets more than that in China. For example, based on La Porta et al. (1998) ${ }^{[10]}$ and Allen et al. (2005) ${ }^{[11]}$, the rule of law index (corruption index) is 8.22 (8.52) for Hong Kong and 8.57 (9.10) for the U.K., compared to 5.0 (2.0) for Mainland China. In addition, Sun et al. (2006) and Yang and Lau (2006) refer to Hong Kong listings of Chinese firms as foreign listings ${ }^{[12,13]}$, Walter and Howie (2006) classify Hong Kong listings as international listings ${ }^{[14]}$. Further, prior cross-country studies generally treat mainland China and Hong Kong as two separate markets, even though they cover sample periods after 1997 (e.g., Lel and Miller, 2008). ${ }^{[15]}$

\subsection{Research Hypotheses}

Companies listed in Hong Kong bond themselves with more stringent legal systems and regulatory regimes, for the behavior of companies' financial reports, the strict legal regulation is reflected in two aspects: on one hand, provide the mandatory disclosure standards, formulate basic rules of financial reporting, such as accounting standards; on the other hand, provide that the company will suffer the legal or administrative penalties if they violate the rules, the mandatory corporate financial reporting rules must be followed. Numerous law and finance literatures have shown that the strict legal regulation and investor protection can promote companies to disclose information more fully, inhibit the earnings management behavior, and enhance the information content of accounting earnings. The legal protection of investors can also reduce the interest conflicts between shareholders and management (Doidge et al, 2004) ${ }^{[1]}$, and the interest conflict between large shareholders and minority shareholders, which also helps to inhibit the company's earnings management behavior.

Hong Kong's securities market constraint on the behavior of the company's financial reports, is reflected in the various market factors affecting the company's incentive to make a reasonable accounting choice within the range allowed by the Accounting Standards. Because of the complexity and uncertainty of the economic activities, no matter how stringent accounting standards are, they must leave the accounting staffs adequate accounting policy choices. Within the limits prescribed by the Accounting Standards, manipulating accounting earnings is not subject to the constraints of the legal and regulatory system, but it will be influenced by market factors. The accounting information provided by the company are mainly used by investors, financial analysts and other capital market players, and they use their professional capacity to analyze the accounting information, and thus play a strong oversight role. Once the behavior of companies to manipulate financial reporting to be identified, the market will quickly respond: lowered its market pricing and increase its financing costs. When companies disclose the high quality accounting information, the market reaction is opposite. Lezu,(2006) suggest that there is a great difference with the company's financial reporting incentives in different market environments ${ }^{[16]}$. More company's financial information investors, financial analysts and other market players take advantage of, the higher request of the information quality, the 
stronger constraints on company earnings management. Ball (2003) and other extensive literatures provide empirical evidence that market factors affect the company's earnings quality ${ }^{[17]}$.

According to the bonding theory, the cross listed companies must face more stringent legal regulatory and market constraints. This helps to compress company's earning management space, increase the punishment of earning management, and reduce the incentive of earning management, and ultimately reduce earning management behavior. Furthermore, the strengthening of the legal regulatory and market constraints due to the cross listing can also change the behavior of the financial reports of the company in domestic. Under the policy of "one country, two systems", Hong Kong still retains the British common law and an independent judiciary. According to the index of anti-director rights built by La Porta et al. (1998) ${ }^{[10]}$, Hong Kong's score matches with the United Kingdom's and the United States', which shows a relatively complete legal protection of investors. Hong Kong's financial market is more developed than mainland market which is established in a short time. Institutional investors, financial analysts, investment banks, and many other subjects in Hong Kong market are very active, they are concerned about the company's long-term investment value, emphasizing fundamental analysis, emphasis on taking full advantage of accounting information, and they can identify the quality of accounting information effectively. In one word, the advantages of legal regulatory and market environment are more obvious. Thus, we propose assumption 1 .

H1: Due to the existence of bonding effect of cross listing, the AH-share companies have higher earning qualities than the paired A-share companies.

Agency problems of state-owned enterprises also exist in private enterprises. State holding listed companies are not profitable for the only goal, it bears a lot of social responsibilities, such as social stability, employment and so on; at the same time, compared with the non-state-owned companies, state-owned companies can get more government support in the financial and political respects, and the government leaders have the incentives to help state-owned companies, because the success of the state-owned companies can bring more resources to the government, so as to enhance their political capital and promotion opportunities. The preferential treatment of state-owned companies given by State-owned banks in lending, also consider the political, social and tax factors, rather than economic factors. Aharony et al (2000) shows that Chinese listed companies have motivation of earning management in IPO, but the companies in protected industry can be given preferential treatment by the government in the process of selecting the listing ones, that is, the stock market regulator is also driven by political considerations rather than economic considerations and privilege the priority of listing for state-owned companies. Kato and Long (2006) test the relationship between ownership property and executives replacement of the controlling shareholders, and they find that the replacement of state-controlled listed company executives presents relatively low sensitivity of performance. Relative to managers of state-owned enterprises, the managers of non-state-owned enterprises are facing greater market pressure, so they have greater motivation for the positive earning management to improve the company reported results, in order to gain market confidence in them. In addition, in order to obtain the IPO listing eligibility, to obtain additional allotment status, to avoid losses and to avoid delisting are important motivations for Chinese listed companies to manage earnings. Though the original intention to establish China's stock market is to solve the problem of low operating efficiency of state-owned enterprises, state-owned enterprises will inevitably subject to special care in the IPO, re-financing and other aspects, therefore the positive earning management motivation of state-owned enterprises is relatively low (Bo and $\mathrm{Wu}, 2009)^{[18]}$. In this context, relative to state-owned enterprises, the bonding effect of cross listing is more obvious with the non-state-owned enterprises. Thus, we propose assumption 2.

H2: Compared with the state-owned enterprises, non-state-owned enterprises which list in Hong Kong have more obvious bonding effect, and thus the earning qualities of non-state-owned enterprises listed in Hong Kong is improved much higher. 


\section{Sample Data and Research Design}

\subsection{Sample Data}

The data is obtained from CSMAR database and Genius Finance database, and the A-share financial data is from CSMAR database, while the AH share financial data is from the Genius Finance database. The information about the date of the A-share company listed in Hong Kong needed to know in the pairing process are manually collected from the HKEx website. Finally, the sample of the non-financial companies includes observations of AH shares for 259, observations of A shares for 518, a total of 777 samples. Specifically, we classify the AH -share companies and the A-share companies as non-state-owned enterprises (NSO) and state-owned enterprises (State-owned, $\mathrm{SO}$ ), in the case of excluding samples of missing important variables, we obtain the sample distribution shown in Table 1.

Table 1. Total of the Original Sample Distribution

\begin{tabular}{|c|c|c|c|c|c|c|c|}
\hline & 2009 & 2010 & 2011 & 2012 & 2013 & 2014 & Total \\
\hline AH-share companies & 30 & 34 & 43 & 48 & 50 & 54 & 259 \\
\hline Including SO companies & 24 & 27 & 31 & 39 & 37 & 40 & 198 \\
\hline Including NSO companies & 6 & 7 & 12 & 9 & 13 & 14 & 61 \\
\hline $\begin{array}{l}\text { A-share companies ( paired } \\
\text { samples) }\end{array}$ & 60 & 68 & 86 & 96 & 100 & 108 & 518 \\
\hline Including SO companies & 55 & 65 & 85 & 92 & 99 & 108 & 504 \\
\hline Including NSO companies & 5 & 3 & 1 & 4 & 1 & 0 & 14 \\
\hline Total & 90 & 102 & 129 & 144 & 150 & 162 & 777 \\
\hline
\end{tabular}

\subsection{The Measurement of Bonding Effect}

There are many indicators in literatures to measure bonding effect, which mainly include market reaction, Tobin's Q, financial performance, company stock liquidity and volume, the company risk level, the cost of capital, corporate governance structure and so on. This paper will use earning qualities as the measurement of bonding effect, and in order to reduce the measurement noise, we use multiple measures of earnings quality which include accounting conservatism, value relevance and the degree of earnings management.

Following Leuz et al (2003) ${ }^{[19]}$, we use indicators which can reflect the information content of accounting earnings: accounting conservatism indicators, value relevance indicators and the level of earning management indicators (items below the line, small positive profit, and large losses). Multi-indicators can reduce endogeneity problems of the measurement of earning managements and mitigate the potential impact of possible missing variables.

\subsection{The Testing Models}

\subsubsection{Accounting Conservatism Model}

Following Basu (1997) ${ }^{[20]}$, introduced dummy variable $\mathrm{AH}$, the model is as follows:

$$
\frac{E P S_{j, t}}{P_{j, t-1}}=\beta_{0}+\beta_{1} D_{j, t}+\beta_{2} R_{j, t}+\beta_{3} D_{j, t} R_{j, t}+\beta_{4} A H_{j, t}+\beta_{5} A H_{j, t} D_{j, t}+\beta_{6} A H_{j, t} R_{j, t}+\beta_{7} A H_{j, t} D_{j, t} R_{j, t}+\mu_{j, t}
$$

where $E P S_{j, t}$ is the earnings per share for firm $j$ in fiscal year $t, P_{j, t-1}$ is the price per share for firm $j$ at the ending of the fiscal year $\mathrm{t}-1, \mathrm{R}_{\mathrm{j}, \mathrm{t}}$ is the annual stock return not considering annual cash dividend reinvestment for firm $j$ in fiscal year $t-1$. $D_{j t}$ is a dummy variable, $D_{j t}=1$ if $R_{j t}<0, D_{j t}=0$ otherwise. $\mathrm{AH}_{\mathrm{j}, \mathrm{t}}$ is dummy variable of whether the company issues A share and $\mathrm{H}$ share at the same time, if it is, $\mathrm{AH}_{\mathrm{j}, \mathrm{t}}=1$, otherwise $\mathrm{AH}_{\mathrm{j}, \mathrm{t}}=0$. When the coefficient $\beta_{7}$ is significantly positive and greater than 0 , we believe that the accounting conservatism of companies which issue A shares and $\mathrm{H}$ shares at the same time is better than companies which issue A shares only, and then from the accounting conservatism perspective, the AH-share company's earning quality is better than the A-share company's earning 
quality.

\subsubsection{Value Relevance Model}

Following Lang, Raedy and Wilson (2006) ${ }^{[21]}$, we establish the model as follows:

$$
P_{j, t}=\alpha_{0}+\alpha_{1} B P S_{j, t}+\alpha_{2} E P S_{j, t}+\alpha_{3} A H_{j, t}+\alpha_{4} A H_{j, t} * B P S_{j, t}+\alpha_{5} A H_{j, t} * E P S_{j, t}+\alpha_{6} A H_{j, t} * B P S_{j, t} * E P S_{j, t}+\varepsilon_{j, t .}
$$

where $\mathrm{BPS}_{\mathrm{j}, \mathrm{t}}$ is net assets per share for $\mathrm{j}$ firm in year $\mathrm{t}$, and the remaining variables are the same as the above; when the coefficient $\alpha_{6}$ is greater than 0 and significantly positive, we believe that the value relevance of the company issuing A shares and $\mathrm{H}$ shares at the same is better than the company issuing A shares only.

\subsubsection{The Measurement of Earning Management Model}

According to Leuz et al (2003) ${ }^{[19]}$, we construct the following regression model to explore the impact of overseas listing on earnings management:

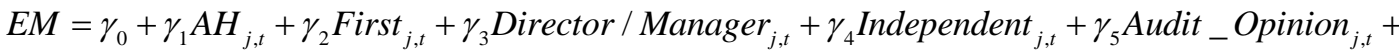

$$
\begin{aligned}
& \gamma_{6} \text { Assets }_{j, t}+\gamma_{7} \text { Age }_{j, t}+\gamma_{8} \text { Board_Meeting }_{j, t}+\gamma_{9} \text { Stockholder_Meeting }_{j, t}+\xi_{j, t .}
\end{aligned}
$$

where EM is earning management indictor, the proposed earnings management indicators include: the-below-line-item indicator (EM_below) equals to "(investment income + non-operating income non-operating expenses) / the total assets of the end of prior period", the smaller the correlation coefficient is, the lower the degree of earning management is, the better earning quality is; according to Burgstahler and Dichev (1997) ${ }^{[22]}$, the definition of small positive profit and large losses depends on the value of annual net income / the total assets of the ending, when the value ranges from 0 to 0.01 , it's small positive profit (EM_smallpositive), the smaller the correlation coefficient is, the lower frequency the small positive profit phenomenon exists, indicting that the lower the degree of earning management is, the better the earning quality is; when the value is less than -0.2 , we define it as large losses (EM_largeloss), the larger the correlation coefficient is, the greater frequency large losses phenomenon exist, the lower the degree of earning management is, the loss is recognized in a timely manner, the higher the earning quality is.

\section{Empirical Results and Analysis}

Table 2 to Table 5 are respectively the regression results of accounting conservatism model, value relevance model, and the degree of earning management model. Table 2 shows that, the coefficient $\beta_{7}$ is 0.05473 , significantly positive at the $10 \%$ level, which shows that the companies which issuing A shares and $\mathrm{H}$ shares at the same time reflect faster on the bad news than the companies which issuing A shares only. In the other word, the accounting conservatism for AH-share companies is better than the A-share companies. Through Table 3 and Table 4 we can see that, the value of coefficient $\eta_{6}$ and $\alpha_{6}$ is 7.16572 and 1.04532 respectively, and both significantly positive at the $1 \%$ level, which shows that the value relevance of the companies which issuing A shares and $\mathrm{H}$ shares at the same time is better than the companies which issuing A shares only. Table 5 lists the regression results of the small positive profit indicator, the large losses indicator, and the below line item indicator on dummy variable $\mathrm{AH}$. We can see that, the degree of large losses for $\mathrm{AH}$-share companies is significantly positive at the $5 \%$ level, indicates that the $\mathrm{AH}$-share companies have a higher frequency of large losses, and a lower degree of earnings management; meanwhile, from the perspective of 
below-line-item indicator, the coefficient of AH dummy variable is negative, but not significant; while the results of small positive profit indicator seems to contradict with predictable conclusions, the small positive profit phenomenon frequency for AH-share companies is higher than the A-share companies, which needs further study.Based on the above regression results, the accounting conservatism and value relevance for $\mathrm{AH}$-share companies is better than $\mathrm{A}$-share companies, and the level of earnings management for $\mathrm{AH}$-share companies is lower than $\mathrm{A}$-share companies, which show that due to the more stringent law regulatory and market constraints of the Hong Kong market, the companies listed in Hong Kong have the bonding effect, and play an inhibition role on earnings management, which consistent with our hypothesis.

Table 2. Regression results of Accounting Conservatism

\begin{tabular}{|c|c|c|c|c|c|}
\hline \multirow{2}{*}{\multicolumn{2}{|c|}{ Accounting Conservatism }} & \multicolumn{2}{|c|}{ Unstandardized coefficients } & \multirow[b]{2}{*}{$\mathrm{t}$} & \multirow[b]{2}{*}{ Sig. } \\
\hline & & $\beta$ & Standard Errors & & \\
\hline \multirow{8}{*}{$\begin{array}{l}\text { Sample } \\
=715 \\
\text { F } \\
=22.208 \\
\text { Adjusted } \\
\text { R2=0.172 }\end{array}$} & (Constant) & .03519 & .00553 & 6.36404 & .00000 \\
\hline & $\mathrm{D}_{\mathrm{j}, \mathrm{t}}$ & .00746 & .01003 & .74315 & .45764 \\
\hline & $\mathrm{R}_{\mathrm{j}, \mathrm{t}}$ & .02080 & .00285 & 7.30162 & .00000 \\
\hline & $D_{j, t} R_{j, t}$ & .02409 & .01874 & 1.28559 & .19901 \\
\hline & $\mathrm{Ah}_{\mathrm{j}, \mathrm{t}}$ & .00026 & .00952 & .02726 & .97826 \\
\hline & $\mathrm{AH}_{\mathrm{j}, \mathrm{t}} * \mathrm{D}_{\mathrm{j}, \mathrm{t}}$ & .00610 & .01699 & .35916 & .71958 \\
\hline & $\mathrm{AH}_{\mathrm{j}, \mathrm{t}} * \mathrm{R}_{\mathrm{j}, \mathrm{t}}$ & -.01078 & .00540 & -1.99572 & .04635 \\
\hline & $\mathrm{AH}_{\mathrm{j}, \mathrm{t}} * \mathrm{D}_{\mathrm{j}, \mathrm{t}} * \mathrm{R}_{\mathrm{j}, \mathrm{t}}$ & .05473 & .03058 & 1.78948 & .07397 \\
\hline
\end{tabular}

Table 3. Regression results of Level and Changes of Incomes

\begin{tabular}{|c|c|c|c|c|c|}
\hline \multirow{2}{*}{\multicolumn{2}{|c|}{ Level and Changes of Incomes Model }} & \multicolumn{2}{|c|}{ Unstandardized coefficients } & \multirow[b]{2}{*}{$\mathrm{t}$} & \multirow[b]{2}{*}{ Sig. } \\
\hline & & $\eta$ & Standard Errors & & \\
\hline \multirow{8}{*}{$\begin{array}{l}\text { Sample } \\
=715 \\
F=29.380 \\
\text { Adjusted } \\
\text { R2=0.218 }\end{array}$} & (Constant) & -1.58962 & 0.69503 & -2.28711 & 0.02248 \\
\hline & $\mathrm{AH}_{\mathrm{j}, \mathrm{t}}$ & 0.13565 & 0.11397 & 1.19021 & 0.23436 \\
\hline & 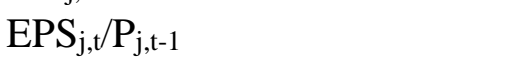 & 10.65269 & 0.98098 & 10.85920 & 0.00000 \\
\hline & $\mathrm{AH}_{\mathrm{j}, \mathrm{t}} * \mathrm{EPS}_{\mathrm{j}, \mathrm{t}} / \mathrm{P}_{\mathrm{j}, \mathrm{t}-1}$ & -5.27943 & 1.59696 & -3.30592 & 0.00099 \\
\hline & $\triangle \mathrm{EPS}_{\mathrm{j}, \mathrm{t}} / \mathrm{P}_{\mathrm{j}, \mathrm{t}-1}$ & 1.21346 & 0.53637 & 2.26234 & 0.02398 \\
\hline & $\mathrm{AH}_{\mathrm{j}, \mathrm{t}} * \triangle \mathrm{EPS}_{\mathrm{j}, \mathrm{t}} / \mathrm{P}_{\mathrm{j}, \mathrm{t}-1}$ & -0.83422 & 0.77359 & -1.07838 & 0.28123 \\
\hline & $\mathrm{AH}_{\mathrm{j}, \mathrm{t}} * \mathrm{EPS}_{\mathrm{j}, \mathrm{t}} / \mathrm{P}_{\mathrm{j}, \mathrm{t}-1} * \triangle \mathrm{EPS}_{\mathrm{j}, \mathrm{t}} / \mathrm{P}_{\mathrm{j}, \mathrm{t}-1}$ & 7.16572 & 2.29318 & 3.12480 & 0.00185 \\
\hline & MVE $_{j, t}$ & 0.07717 & 0.03088 & 2.49871 & 0.01269 \\
\hline
\end{tabular}

Table 4. Regression results of value relevance( Price Model)

\begin{tabular}{|c|c|c|c|c|c|}
\hline \multirow{2}{*}{ Price Mode } & & \multicolumn{2}{|c|}{ Unstandardized coefficients } & \multirow[b]{2}{*}{$\mathrm{t}$} & \multirow[b]{2}{*}{ Sig. } \\
\hline & & $\alpha$ & Standard Errors & & \\
\hline \multirow{7}{*}{$\begin{array}{l}\text { Sample } \\
=719 \\
F=68.909 \\
\text { Adjusted } \\
\text { R2=0.362 }\end{array}$} & (Constant) & -1.54915 & 1.18602 & -1.30617 & .19191 \\
\hline & $\mathrm{BPS}_{\mathrm{j}, \mathrm{t}}$ & 3.86510 & .24187 & 15.97976 & .00000 \\
\hline & $\mathrm{EPS}_{\mathrm{j}, \mathrm{t}}$ & 1.17340 & .90432 & 1.29755 & .19486 \\
\hline & $\mathrm{AH}_{\mathrm{j}, \mathrm{t}}$ & 6.87100 & 2.15100 & 3.19433 & .00146 \\
\hline & $\mathrm{AH}_{\mathrm{j}, \mathrm{t}} * \mathrm{BPS}_{\mathrm{j}, \mathrm{t}}$ & -3.24047 & .64781 & -5.00216 & .00000 \\
\hline & $\mathrm{AH}_{\mathrm{j}, \mathrm{t}} * \mathrm{EPS}_{\mathrm{j}, \mathrm{t}}$ & 4.77871 & 2.16311 & 2.20918 & .02748 \\
\hline & $\mathrm{AH}_{\mathrm{j}, \mathrm{t}} * \mathrm{BPS}_{\mathrm{j}, \mathrm{t}} * \mathrm{EPS}_{\mathrm{j}, \mathrm{t}}$ & 1.04532 & .29816 & 3.50586 & .00048 \\
\hline
\end{tabular}


Table 5. Regression Results of Earnings Quality indicators and Cross Listing factor model

\begin{tabular}{|c|c|c|c|}
\hline \multirow[b]{2}{*}{$\begin{array}{c}\text { Explanatory } \\
\text { Variables }\end{array}$} & \multicolumn{3}{|c|}{$\gamma$} \\
\hline & $\begin{array}{c}\text { Small Positive } \\
\text { Profits }\end{array}$ & $\begin{array}{l}\text { Large } \\
\text { Losses }\end{array}$ & $\begin{array}{l}\text { Below-line } \\
\text { Items }\end{array}$ \\
\hline (Constant) & $\begin{array}{c}0.252 \\
(1.214)\end{array}$ & $\begin{array}{c}0.033 \\
(0.837)\end{array}$ & $\begin{array}{c}0.018 \\
(1.003)\end{array}$ \\
\hline $\mathrm{AH}_{\mathrm{j} . \mathrm{t}}$ & $\begin{array}{c}0.031 \\
(1.298)\end{array}$ & $\begin{array}{l}0.009 * * \\
(2.002)\end{array}$ & $\begin{array}{c}-0.002 \\
(-0.873)\end{array}$ \\
\hline First $_{j . t}$ & $\begin{array}{l}-0.148^{*} \\
(-1.949)\end{array}$ & $\begin{array}{c}0.005 \\
(0.323)\end{array}$ & $\begin{array}{c}0.007 \\
(1.046)\end{array}$ \\
\hline Director/Manager $_{j . t}$ & $\begin{array}{c}-0.061 \\
(-1.475)\end{array}$ & $\begin{array}{l}0.017 * * \\
(2.201)\end{array}$ & $\begin{array}{c}0.017 * * * \\
(4.809)\end{array}$ \\
\hline Indepent $_{\mathrm{j} . t}$ & $\begin{array}{c}0.046 \\
(0.275)\end{array}$ & $\begin{array}{c}-0.006 \\
(-0.183)\end{array}$ & $\begin{array}{c}-0.006 \\
(-0.416)\end{array}$ \\
\hline Audit Opinion ${ }_{j . t}$ & $\begin{array}{c}-0.017 \\
(-0.281)\end{array}$ & $\begin{array}{c}-0.038 * * * \\
(-3.294)\end{array}$ & $\begin{array}{c}-0.006 \\
(-1.148)\end{array}$ \\
\hline Assets $_{j . t}$ & $\begin{array}{c}-0.005 \\
(-0.515)\end{array}$ & $\begin{array}{c}0.000 \\
(-0.096)\end{array}$ & $\begin{array}{c}-0.001 \\
(-0.959)\end{array}$ \\
\hline Age $_{j . t}$ & $\begin{array}{c}0.002 \\
(0.760)\end{array}$ & $\begin{array}{l}0.001 * \\
(1.730)\end{array}$ & $\begin{array}{c}0.001 * * * \\
(3.785)\end{array}$ \\
\hline Board Meeting ${ }_{j . t}$ & $\begin{array}{c}-0.002 \\
(-0.771)\end{array}$ & $\begin{array}{c}-0.001 \\
(-1.324)\end{array}$ & $\begin{array}{c}0.001 * * * \\
(3.342)\end{array}$ \\
\hline Stockholder & 0.004 & 0.002 & 0.001 \\
\hline Meeting $_{\mathrm{j} . t}$ & $(0.547)$ & $(1.288)$ & $(0.834)$ \\
\hline Sample & 696 & 696 & 696 \\
\hline F value & 1.234 & 3.072 & 6.598 \\
\hline Adjusted $\mathrm{R}^{2}$ & 0.003 & 0.026 & 0.067 \\
\hline
\end{tabular}

\section{Conclusions}

Using the accounting conservatism, value relevance and earning management as the measure for cross listing bonding effect, this paper studies the existence of bonding effect for cross listing firms . The result shows that bonding effect exists in firms which list in Hong Kong, and the effect significantly improves firms' earning qualities.

\section{References}

[1] Doidge C, Karolyi G A, Stulz R M. Why Are Foreign Firms Listed in the U.S. Worth More? [J]. Journal of Financial Economics, 2004, 71(2): 205-238.

[2] Coffee, J. The future as history: The prospects for global convergence in corporate governance and its implications[J]. Northwestern University Law Review, 1999, (93): 641-708.

[3] Coffee, J. Racing towards the top? The impact of cross-listings and stock market competition on international corporate governance[J]. Columbia Law Review, 2002, (102): 1757-1831.

[4] Stulz, R. Globalization, corporate finance, and the cost of capital [J]. Journal of Applied Corporate Finance, 1999, (26): 3-28. 
[5] Foerster S R, Karolyi G A. The Effects of Market Segmentation and Investor Recognition on Asset Prices: Evidence from Foreign Stocks Listing in the United States [J]. Journal of Finance, 1999, 54(3): 981-1013.

[6] Lang M H, Lins K V, Miller D P. Adrs, Analysts, and Accuracy: Does Cross Listing in the United States Improve a Firml"S Information Environment and Increase Market Value? [J]. 2003, 41(2): 317-345.

[7] Bauer, R; Wojcik, Dariusz and Clark, Gordon Leslie. Corporate governance and cross -listing: evidence from European companies. Working paper. Oxford University

Center for the Environment, 2004.

[8] Licht A N. Cross-Listing and Corporate Governance: Bonding or Avoiding? [J]. Chicago Journal of International Law, 2003, 737(1): 141-163.

[9] Siegel J. Can Foreign Firms Bond Themselves Effectively by Renting U.S. Securities Laws? [J]. 2005, 75(2): 319-359.

[10] La Porta, R.; Lopez-de-Silanes, F.; Shleifer, A., and Vishny, R. W. Law and finance[J]. Journal of Political Economy, 1998, (106) : 1112 - 1155.

[11] Allen,F.;Qian,J.;Qian,M. Law, finance, and economic growth in China[J]. Journal of Financial Economics,2005,(77):57-116.

[12] Yang, T.and Lau, S.T. Choice of foreign listing location: experience of Chinese firms[J]. Pacific-Basin Finance Journal, 2006, (14): 311-326.

[13] Sun,Q.;Tong, W.;Wu,Y. The Choice of foreign primary listing: China's share-issue privatization experience. Working paper. Hong Kong Poly Technic University. 2006.

[14] Walter, C., Howie, F. Privatizing China[M]. Wiley, Singapore, 2006.

[15] Lel, U., Miller, D. International cross-listing, firm performance and top management turnover: a test of the bonding hypothesis[J]. The Journal of Finance,2008, (63): 1897-1937.

[16] Leuz, C. Cross listing, bonding and firms' reporting incentives: A discussion of Lang, Raedy and Wilson[J]. Journal of Accounting and Economics, 2006, (42): 285-299.

[17] Ball, R.; S. P. Kothari and A. Robin. The effect of international institutional factors on properties of accounting earnings[J]. Journal of Accounting and Economics, 2000, (29): 1-51.

[18] Bo Xianhui, Wu Liansheng. Effect of the governance of state-owned holding institutional investors: from earnings management perspective[J].Economic Research,2009(2):81-91.

[19]Leuz C, Nanda D, Wysocki P D. Earnings Management and Investor Protection: An International Comparison [J]. Journal of Financial Economics, 2003, 69(3): 505-527.

[20]Basu S. The Conservatism Principle and the Asymmetric Timeliness of Earnings [J]. Contemporary Accounting Research, 1997, 24(1): 215-241.

[21]Lang M, Raedy J S, Wilson W. Earnings Management and Cross Listing: Are Reconciled Earnings Comparable to Us Earnings? [J]. Journal of Accounting \& Economics, 2006, 42(1-2): $0-283$.

[22]Burgstahler D, Dichev I. Earnings Management to Avoid Earnings Decreases and Losses [J]. Social Science Electronic Publishing, 1997, 24(1): 99-126. 